\title{
Proposals to improve the coaxial cable assembly process in an aerospace company
}

\section{Propuestas para mejorar el proceso de montaje de cables coaxiales en una empresa aeroespacial}

PORTUGAL-VÁSQUEZ, Javier†๋*, SANDOVAL-GAMEZ, Melissa, LAGARDA-LEYVA, Ernesto Alonso and NARANJO-FLORES, Arnulfo Aurelio

Instituto Tecnológico de Sonora. Departamento de Ingeniería Industrial

ID $1^{\text {st }}$ Author: Javier, Portugal-Vásquez / ORC ID: 0000-0002-8986-2023, CVU CONACYT ID: 249136

ID $1{ }^{\text {st }}$ Co-author: Melissa, Sandoval-Gamez / ORC ID: 0000-0002-2318-897X

ID $2^{\text {nd }}$ Co-author: Ernesto Alonso, Lagarda-Leyva / ORC ID: 0000-0001-9552-9908, CVU CONACYT ID: 433524

ID $3^{\text {rd }}$ Co-author: Arnulfo Aurelio, Naranjo-Flores / ORC ID: 0000-0002-5654-6091, CVU CONACYT ID: 276441

DOI: $10.35429 / J R D \cdot 2021.20 .7 .27 .38$

Received July 17, 2021; Accepted October 30, 2021

\begin{abstract}
For any company it is of utmost importance to have quality processes and products to deliver to its customers and that they are satisfied with them. In the same way, take care of your economy and the expenses that you have for this. This project revolves around the quality that is presented in the products. In the company under study there was a problem specifically in the area of coaxial cable assembly, in which a considerable number of defects were identified from the electrical and continuity test. To solve the problem, the objective is to develop an improvement proposal that helps to minimize the defects found in the aforementioned area. Regarding the applied method, the modified Six Sigma DMAIC procedure was followed. Statistical tools were used to analyze the results obtained, to have evidence of their behavior for the problem posed and that the best decision could be made to improve the coaxial cable assembly process. Having as a main result a proposal to improve the coaxial cable assembly process which will significantly reduce the defects generated in the electrical and conductivity test.
\end{abstract}

DMAIC, Continuous improvement, Quality

\begin{abstract}
Resumen
Para cualquier empresa es de suma importancia el tener procesos y productos de calidad que entregarles a sus clientes y que estos estén conformes con ellos. De igual manera cuidar su economía y los gastos que se tiene por esto. El presente proyecto gira entorno a la calidad que se presenta en los productos. En la empresa bajo estudio se presentó un problema específicamente en el área de ensamble de cables coaxiales, en la cual se identificaban una cantidad considerable de defectos provenientes de la prueba eléctrica y continuidad. Para resolver el problema se plantea el objetivo de desarrollar propuesta de mejora que ayuden a minimizar los defectos que se encuentran en el área antes mencionada. En cuanto al método aplicado se siguió el procedimiento DMAIC de Seis Sigma modificada. Se utilizaron herramientas estadísticas para analizar los resultados obtenidos, para tener evidencias del comportamiento de los mismos para el problema planteado y que se pudiera tomar la mejor decisión para mejorar el proceso de ensamble de cables coaxiales. Teniéndose como resultado principal una propuesta de mejora al proceso de ensamble de cables coaxiales la cual reducirá significativamente los defectos generados en la prueba eléctrica y conductividad.
\end{abstract}

DMAIC, Mejora continua, Calidad

Citation: PORTUGAL-VÁSQUEZ, Javier, SANDOVAL-GAMEZ, Melissa, LAGARDA-LEYVA, Ernesto Alonso and NARANJO-FLORES, Arnulfo Aurelio. Proposals to improve the coaxial cable assembly process in an aerospace company. Journal of Research and Development. 2021. 7-20: 27-38

\footnotetext{
* Correspondence to Author (e-mail: javier.portugal@itson.edu.mx)

$\dagger$ Researcher contributing as first author.
} 


\section{Introduction}

The manufacturing industry according to the National Institute of Statistics and Geography (INEGI, 2014) defines as the economic activity that transforms raw materials into different items for consumption. According to the type of product that is made, they are classified into 10 types of activity: Food Products, beverages and tobacco, Machinery and Equipment, Petroleum and coal derivatives, chemical industries of plastic and rubber, Metal industries, Products based on non-metallic minerals, Textile industries, clothing and leather industries, Paper, Printing and related industries, Other manufacturing industries, Wood industry, Manufacture of furniture and related products.

Within the manufacturing industry, specifically in the type of machinery and equipment, several activities are included, such as agricultural activities, extractive industry, aerospace industry, among others. The aerospace industry is engaged in the construction, design, operation, and maintenance of equipment that is intended to be used within the Earth's atmosphere and outside it. Having a worldwide value of 450, 000 million dollars. (Medina, 2012).

In Mexico, the aerospace sector is made up of companies that are dedicated to the manufacture, repair, adaptation, engineering, design, and auxiliary services of commercial and military aircraft. The country has managed to consolidate itself as a global leader in this sector. (Pro-Mexico, 2014).

According to the Mexican Federation of the Aerospace Industry (FEMIA, 2012), the aerospace sector is related to continuous innovation and the development of new technologies and cutting-edge materials, to contribute to the economic and social development of the countries in which it is developed. This sector is a key point for the generation of jobs and wages.

In Mexico, the aerospace industry is made up to a greater extent of foreign companies (Forbes, 2014), because the country focuses this activity on supplying the international market. During the period 2004-2013 Mexico had a 17\% increase in its annual exports, representing revenues of 4,412 million dollars in 2013.
In Mexico, there are 287 industries in the aerospace sector, most of which have AS9100 Quality certifications, which is an adaptation of ISO 9001, with additional considerations for companies in this sector. Industries are mainly located in five states of the country. (Pro México, 2014).

According to the Council for Economic Promotion in Sonora (COPRESON, 2012) in Sonora, there are more than 45 manufacturing industries in the aerospace sector, all of the foreign investment, mainly of North American, British and French origin. These industries represent $50 \%$ of manufacturing activity in Mexico in the sector.

The company under study is a global manufacturer of interconnection components, offers products such as connectors, fiber optics, coaxial cables, multipin, antennas, space components, among others. The company is present in 3 continents and 13 countries, with specialized centers, offering its customers innovative products, personalized attention, and superior logistics.

The company produces a wide variety of products that are used in the aerospace industry, the area under study is that of Coaxial Cables. In this area, a great variety of them is assembled, which are semi-rigid or flexible. Each cable is different, but in general, they all contain connectors and cable.

For the area under study, it is essential to control the process of assembling the cables, because it is an artisanal process carried out by the operators. Within the process, it is of utmost importance to be checking the cables during each season before passing them to the next stage of the process, in order to identify if there is any defect, since if they reach the final stage it may be difficult or impossible to correct it.

Despite the efforts to control the quality in the assemblies, defects have occurred during the last year, which compromises the quality of the product and also leads to not reaching the level of its main indicator, which is parts per million (ppm). Table 1 shows the different types of defects in cables. As can be seen, the electrical and conductivity test is the one that represents the highest percentage of appearance with $48.09 \%$. 
The electrical test is one of the last activities that are carried out in the process of assemblies of cables, it causes the rework or production. Which translates into a $20 \%$ increase in raw material cost.

\begin{tabular}{|c|l|r|r|}
\hline \multicolumn{2}{|c|}{$\begin{array}{c}\text { No } \\
.\end{array}$} & $\begin{array}{c}\text { Cumulative } \\
\text { Percentage }\end{array}$ & \multicolumn{1}{c|}{ Percentage } \\
\hline 1 & Electrical Test and Conductivity & $48.09 \%$ & $48.092 \%$ \\
\hline 2 & External Welding Spill & $61.07 \%$ & $12.977 \%$ \\
\hline 3 & Interface Changed & $72.26 \%$ & $11.196 \%$ \\
\hline 4 & Problems Epoxico (spill, foul) & $76.84 \%$ & $4.580 \%$ \\
\hline 5 & Problems with the external conductor (braid) & $81.17 \%$ & $4.326 \%$ \\
\hline 6 & Missing accessories & $83.72 \%$ & $2.545 \%$ \\
\hline 7 & No splint pressing & $86.26 \%$ & $2.545 \%$ \\
\hline 8 & Out-of-specification stripping & $88.55 \%$ & $2.290 \%$ \\
\hline 9 & Splint damage & $90.84 \%$ & $2.290 \%$ \\
\hline 10 & Damaged connector & $92.88 \%$ & $2.036 \%$ \\
\hline 11 & Internal weld spill & $94.66 \%$ & $1.781 \%$ \\
\hline 12 & Other & $96.44 \%$ & $1.781 \%$ \\
\hline 13 & Damaged cable protector & $97.20 \%$ & $0.763 \%$ \\
\hline 14 & Poor box labeling & $97.96 \%$ & $0.763 \%$ \\
\hline 15 & Poor tube/marker shrinkage & $98.73 \%$ & $0.763 \%$ \\
\hline 16 & Damaged external conductor & $98.98 \%$ & $0.254 \%$ \\
\hline 17 & Marker with cut or gaps & $99.24 \%$ & $0.254 \%$ \\
\hline 18 & Bad Pin Presser (Contact) & $99.49 \%$ & $0.254 \%$ \\
\hline 19 & Hole in internal welding & $99.75 \%$ & $0.254 \%$ \\
\hline 20 & No torque (Connector body) & $100.00 \%$ & $0.254 \%$ \\
\hline
\end{tabular}

Table 1 Different types of defects in cables Prepared by the authors

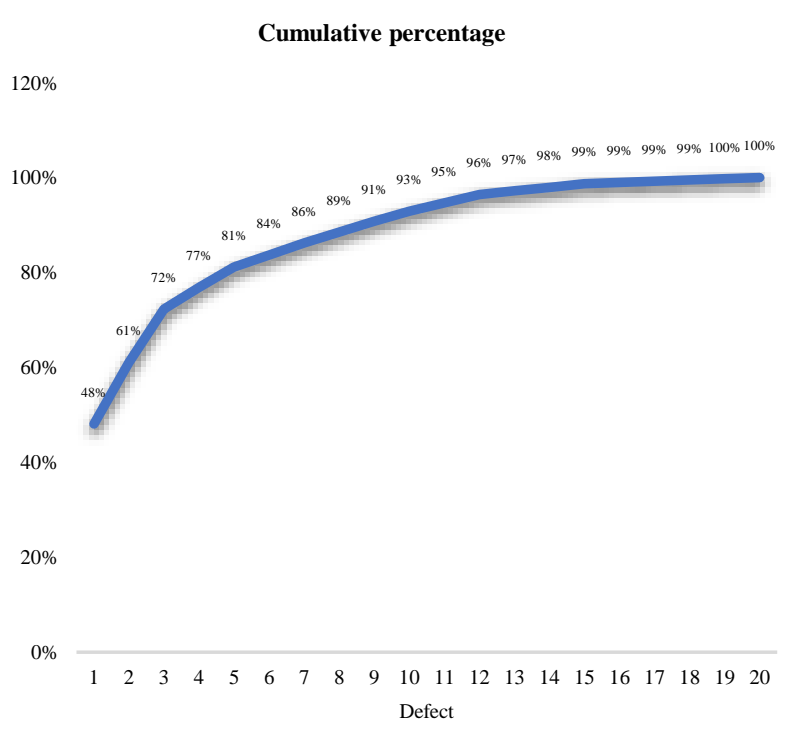

Graph 1 Pareto Chart

Prepared by the authors

At the same time, it generates poor customer service, since your order is not delivered in the time you agreed, due to the rework that is made by the failure in the electrical test and conductivity, translating for the client into poor quality service. Figure 1 shows the Ishikawa Diagram where the possible causes that can cause defects in the product are shown, highlighting in red the causes that are considered the main ones.
The main causes found in the Ishikawa diagram are stripping measurements, the amount of welding, the lack of attention of the operators, the method of welding the connector, and the lack of maintenance of the tools that are used for the development of the process.

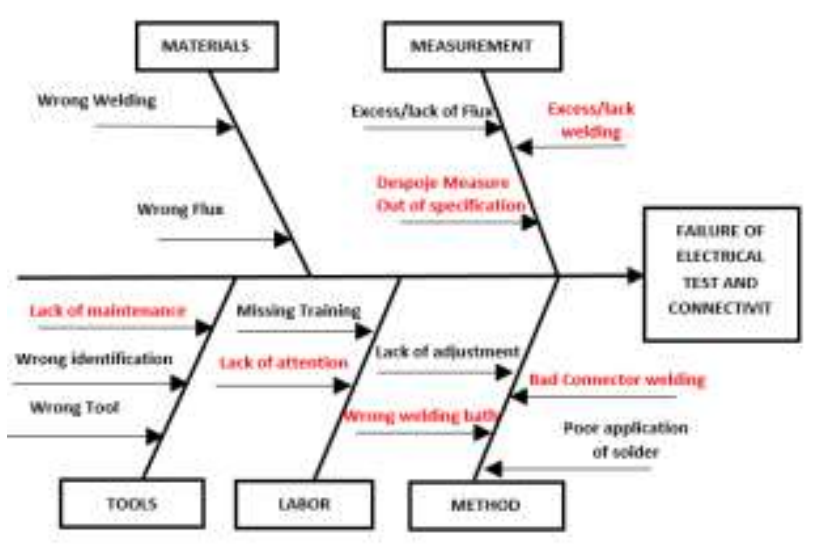

Figure 1 Ishikawa diagram

Prepared by the authors

The company produces a wide variety of products that are used in the aerospace industry, the area under study is that of Coaxial Cables. In this area, a great variety of them is assembled, which are semi-rigid or flexible. Each cable is different, but in general, they all contain connectors and cable. The process is different for each type depending on the client and the utility it will have. The electrical and conductivity test is performed on the cable to determine its resistance and if there is conductivity in it. In case of failure of the test, it indicates that the previous operations are not being carried out as required and the failure in the product.

\section{Problem Statement}

Quality is the characteristic of a product or service that has to satisfy implicit or explicit needs, and in this way obtain the satisfaction of the client that is the perception of the same about whether their needs have been met. (Gutierrez Pulido \& De la Vara Salazar, 2013). In the area under study (Coaxial Cables) it is very important to carry out their quality and without defects, so there is quality control in each season of the process. Even with this in the process, you find defects in the cables as mentioned in the previous section. Therefore, we want to carry out actions that reduce the causes that cause defects in the cables. Which brings us to the following approach: How to reduce the defects that cause failure in the electrical test and conductivity in the process of assemblies coaxial cables? 


\section{Objective}

Develop proposals for improvements to the coaxial cable assembly process, using the Six Sigma methodology, to reduce product defects that cause failure in the electrical test and conductivity.

\section{Justification}

With the above, the company will be able to reduce the defects of the Coaxial Cables product that cause electrical failure and conductivity, significantly reducing the production time of the same by eliminating rework and additional production, and in this way, the company will be able to increase its efficiency in production by being able to increase the number of orders it serves per day. In the same way, the company will have a reduction in its costs production.

\section{Theoretical Foundation}

SixSigma is a philosophy that is oriented to customer satisfaction, using facts and data to generate solutions to problems that affect them. It is aimed at improving customer satisfaction, reducing cycle time and defects. (Pande \& Holpp, 2002). Six Sigma is a statistical measure of the level of performance of a process or product, which aims to achieve almost perfection, providing a management system to achieve leadership in the business where it is applied to have world-class quality. (Pande \& Holpp, 2002)

It is a disciplined approach that is based on the use of statistics to improve business performance, by eliminating defects in an organization's products, processes, and transactions, by decreasing the cost of operation and that of products sold, and by increasing customer satisfaction. (Cantú Delgado, 2011). It is a methodology that is focused on eliminating the defects of a process or product, and in this way reduce the costs of the company where it is applied and most importantly exceed the expectations of the client.

The name Six Sigma is due to the one that refers to six standard deviations from the mean, which is a goal to reduce defects by $99.9997 \%$, or in other words to achieve no more than 3.4 defects per million opportunities (DPMO).
One of the pin companies in the application of the six-sigma methodology was Motorola managed to reduce defects in electronic products and save about 1,000 million dollars during 3 years after implementation and won the Malcolm Baldrige quality award in 1988. At that time, it was adopted, enriched, and generalized by a large number of companies.

In addition to Motorola, two companies contributed significantly to the consolidation of the strategy, Allied Signal that first implemented it in 1994 achieving savings of more than 2,000 million dollars between 1994 and 1999, and General Electric (GE), which made its implemented in 1995 who managed to save around 2,570 million dollars in the following 3 years. In Latin America, the company MABE is the one that has managed to carry out and implement one of the most successful Six Sigma programs. (Gutierrez \& De la Vara, 2013)

There are many reasons that can justify implementing Six Sigma in companies. (Cantu Delgado, 2011)

1. It helps improve the way the business is operated.

2. It helps to visualize the company as an interrelated system of processes and customers.

3. Troubleshoot problems.

4. Decision-making is made based on data.

5. Establish a system that can generate significant revenue, in order to satisfy both internal and external customers. With the above, better competitiveness is ensured and benefits are obtained in less time.

6. You can increase employee productivity with the same resources.

7. Revenue is improved.

8. Customer expectations are exceeded.

9. Give your staff a culture of quality, so they support the changes and be able to maintain the results.

10. If a process has a quality level of Six Sigma, this means that it is capable of generating no more than 3 or 4 defects per million opportunities.

Six Sigma has a wide variety of tools that serve as support in the implementation of the methodology, according to Gutierrez \& De la Vara, (2013) and Pande, Neuman \& Cavanagh, (2004) the basic tools are shown below: 
DMAIC Project Chart Worksheet: This helps the team understand what they want to achieve and identify areas where further clarification is required from the project sponsor.

Pareto Chart: This is a graph that aims to help identify the vital problems you have, as well as the possible causes of them. It helps to prioritize the causes to focus first on the main one and so on to analyze the causes. The usefulness of it is based on the so-called "Pareto Principle", which is known as "Law 80-20" or "Few Vital, Many Trivial", which establishes that few elements (represented by 20\%) generate most of the effect (representing 80\%), and the rest of the pampering has a smaller contribution. Stratification: Stratification means analyzing problems, failures, complaints, or data, classifying them according to the factors that are inferred that may be affecting them, and in this way identify the best ways to solve the problems that arise in a process. This tool makes it easier to understand how the different factors that generate a problematic situation influence.

Ishikawa Diagram: Also called CauseEffect. This is a graphical method that helps to relate a problem (Effect) with the possible causes that generate it. The diagram forces us to look for different causes under analysis and thus avoids looking directly for solutions without analyzing the true causes.

Method of the 6M: This is the most common to build an Ishikawa diagram, it consists of grouping the possible causes into 6 main branches: Working Methods, Labor, Materials, Machinery, Measurement, and Environment. These six elements represent the entire process in a global way since each one contributes part of the variability of the final product.

SIPOC Diagram: The acronym SIPOC comes from suppliers, inputs, processes, outputs, and customers. This diagram aims to analyze the process and its environment, by them the suppliers, inputs, process, outputs, and the customers must be identified. This helps us to know in detail the process that is being analyzed, by identifying what is needed for it to work correctly, the specifications of the users of the process, identify who will provide what is necessary for the process and that is expected to leave the process studied. (Gutierrez, Quality and Productivity, 2014)
CTQ Tree: This helps to relate the measurements to an important output of the process; it is used in data collection to ensure that the information obtained is important for the project.

\section{Hypothesis Testing}

The interest in performing a hypothesis test lies in comparing the strength of two formulations (null and alternative hypothesis), one with the equal variable and the other with the modified variable. It is used to test a hypothesis, for this, it is necessary to perform a procedure to take a random sample, calculate a test statistic that is appropriate, and then reject or not reject the null hypothesis. You must specify the set of test statistic values that will be the rejection region. (Montgomery, 2016)

\section{Design of Experiments}

The design of experiments is the application of the scientific method to generate knowledge about a system or process, through planned tests. This methodology has been consolidated as a set of statistical and engineering techniques, which allow a better understanding of situations of cause-and-effect relationship.

\section{Methodology}

For the realization of this project and the fulfillment of the proposed objective, the DMAIC methodology was followed. The following points describe the activities that were carried out at each stage and the products that were obtained from each of them.

Define the opportunity areas of the coaxial cable assembly process

First, a meeting was held with the stakeholders of the project to collect the relevant information, where the problem that arose in the process of assembling coaxial cables and why it was wanted to be addressed was exposed. With the information obtained, the project charter (Project Charter) was made and the work team was formed. After this, a tour of the area of assembly of coaxial cables was carried out in order to know in detail what is done and identify the workstations, and based on this a SIPOC map was elaborated. The main variables that affect the process and that cause the problem of failure in the electrical test and conductivity were identified. 
Finally, the customer who was affected was identified and their needs and complaints were identified. With the above, a table was made that contained the declaration of the client's requirements of the problem raised.

Measure the critical variables of the coaxial cable assembly process

Once the project was defined, the work team carried out an analysis of the possible causes that caused the problem, for this an Ishikawa diagram (Cause-Effect) was made. After this, the relationship between the customer requirements, raised in the previous stage, and the causes that were identified, were identified through a CTQ tree (Critiques for Quality). After this, a mapping of the coaxial cable assembly process was carried out to analyze what the true magnitude of the problem was, all the process variables and the outputs of the same that could affect the electrical test and conductivity were identified, and a cause-and-effect matrix was made, where the critical variables that were had within the process were found.

After this, a verification of the MEFAs of the process stations was carried out and an EFSM of the preparation station was created and with this, the critical variables of the process were obtained. Finally, the plan for the collection of data was made, which consisted of a database where all the defects they presented were placed, analyzing them with the microscope to identify the possible cause of it. With the data obtained, the performance of the CTQ of the process was measured. The results obtained from the data collection are shown in a table.

Analyze data from critical variables of the coaxial cable assembly process

In this stage, the data obtained in the measurement phase were taken and analyzed to determine which connectors were what had the highest percentage of appearance in the problem, for this a Pareto diagram was made, where the connectors with the highest percentage of appearance of the problem were found, which are connector $\mathrm{A}$ and $\mathrm{B}$. As a result of this phase, you have a Pareto chart and the most important causes that contribute to the problem. To later perform the statistical analysis of the CTQ, from which the variables that were related to the output variable were obtained.
Implement improvement actions for the coaxial cable assembly process

At this stage, solutions that could help achieve the stated objective were established, this was done through brainstorming with team members and identifying changes that could be made to the process. A Design of Experiments was carried out to verify the behavior of different factors on the variables that affect the process. The executions of the design of experiments were carried out. And after this, proposals for improvement were developed for the process of assemblies coaxial cables. Having as a result of this phase the definition of the Designs of Experiments and proposals for improvement to the process.

\section{Results}

\section{Definition of the areas of opportunity of the coaxial cable assembly process.}

Through meetings with interested persons and observation of the coaxial cable assembly area, the results were the Project Charter, a SIPOC map of the coaxial cable assembly process, and the identification of the client and his requirements. Table 2 shows the Project Charter summarized.

\begin{tabular}{|c|c|}
\hline \multicolumn{2}{|c|}{ Project Charter } \\
\hline $\begin{array}{l}\text { Business Case: } \\
\text { Find and reduce the causative } \\
\text { variation that causes products to fail at } \\
\text { the electrical and conductivity test } \\
\text { station }\end{array}$ & $\begin{array}{l}\text { Team Members: } \\
\text { Quality Engineer } \\
\text { Process Engineer }\end{array}$ \\
\hline $\begin{array}{l}\text { Problem/Opportunity Statement: } \\
\text { Variations in assembly in the area of } \\
\text { cables have contributed to the increase } \\
\text { in electrical failure, increasing the } \\
\text { level of ppm, production costs and } \\
\text { delivery times, according to quality } \\
\text { records. }\end{array}$ & $\begin{array}{l}\text { Objective Statement: } \\
\text { To reduce to } 70 \% \text { the } \\
\text { defects of the assembly } \\
\text { process in the area of } \\
\text { coaxial cables in order to } \\
\text { control the failure in the } \\
\text { electrical test in the } \\
\text { electrical test station and } \\
\text { conductivity. }\end{array}$ \\
\hline $\begin{array}{l}\text { Project Scope: } \\
\text { The project will be carried out in the } \\
\text { Coaxial Cables Area specifically the } \\
\text { Welding and Preparation stations. } \\
\text { Aspects of the project will be } \\
\text { reviewed daily and whether it will } \\
\text { have a progress meeting on Mondays. }\end{array}$ & $\begin{array}{l}\text { Stakeholders: } \\
\text { Supervisor of the area. } \\
\text { Process Engineer } \\
\text { AVP Manager }\end{array}$ \\
\hline
\end{tabular}

Table 2 Project Charter (summarized) Prepared by the authors

After the tour of the coaxial cable assembly area, the SIPOC Map was obtained, which is divided by the activities carried out throughout the process. Table 3 shows the SIPOC map of the Contact Welding (PIN) process. 


\begin{tabular}{|c|c|c|c|c|}
\hline Suppliers & Inputs & Process & Outputs & Costumers \\
\hline $\begin{array}{l}\text { External } \\
\text { Suppliers }\end{array}$ & $\begin{array}{l}\text { Welding } \\
\text { specified } \\
\text { in MO }\end{array}$ & \multirow{4}{*}{$\begin{array}{l}\text { Contact } \\
\text { welding } \\
\text { (PIN) }\end{array}$} & $\begin{array}{l}\text { Cable with } \\
\text { welded } \\
\text { contact }\end{array}$ & \multirow{4}{*}{$\begin{array}{l}\begin{array}{l}\text { External } \\
\text { Customer } \\
\text { Correct } \\
\text { delivery of } \\
\text { your product }\end{array} \\
\begin{array}{l}\text { On-time } \\
\text { delivery }\end{array} \\
\begin{array}{l}\text { Quality } \\
\text { product }\end{array}\end{array}$} \\
\hline $\begin{array}{l}\text { Contact } \\
\text { placement }\end{array}$ & $\begin{array}{l}\text { Flux } \\
\text { specified } \\
\text { in MO }\end{array}$ & & No spills & \\
\hline $\begin{array}{l}\text { Human } \\
\text { resources }\end{array}$ & $\begin{array}{l}\text { Cable } \\
\text { with } \\
\text { suitable } \\
\text { contact }\end{array}$ & & $\begin{array}{l}\text { Contact } \\
\text { glued to } \\
\text { the } \\
\text { insulator }\end{array}$ & \\
\hline Tooling & $\begin{array}{l}\text { Welding } \\
\text { tweezers }\end{array}$ & & $\begin{array}{l}\text { Inspection } \\
\text { window } \\
\text { full of } \\
\text { welding }\end{array}$ & \\
\hline
\end{tabular}

Table 3 SIPOC Map, Contact Welding Process (PIN) Prepared by the authors

\section{Customer Requirements Statement}

In this section, the client who was affected by the problem was identified, being the Electrical and Conductivity Test Station, and based on this the Client's Requirements statement was obtained, which requires a cable with transmission and continuity. Table 4 shows the Voice of the Customer.

\begin{tabular}{|l|l|l|}
\hline \multicolumn{1}{|c|}{ The Customer Says } & \multicolumn{1}{c|}{ Meaning } \\
\hline $\begin{array}{l}\text { There is no transmission } \\
\text { in the cable. }\end{array}$ & $\begin{array}{l}\text { The central conductor is } \\
\text { making physical contact } \\
\text { with the body or with the } \\
\text { braid. The central } \\
\text { conductor does not make } \\
\text { contact with the } \\
\text { connector. }\end{array}$ & $\begin{array}{l}\text { Perform cable assembly } \\
\text { processes properly to } \\
\text { avoid the existence of the } \\
\text { problem. }\end{array}$ \\
\hline $\begin{array}{l}\text { When the high-voltage } \\
\text { discharge is realized the } \\
\text { cable has no continuity. }\end{array}$ & $\begin{array}{l}\text { The ideal distance } \\
\text { between the connector } \\
\text { and the braid is not being } \\
\text { respected. }\end{array}$ & $\begin{array}{l}\text { Perform the process of } \\
\text { assembling the cable } \\
\text { taking care of the } \\
\text { distance between the } \\
\text { connector and the central } \\
\text { conductor. }\end{array}$ \\
\hline
\end{tabular}

Table 4 Voice of the Customer Prepared by the authors

\section{Measurement of the critical variables of the coaxial cable assembly process}

In this phase, through observation of the process and active participation of those involved in the coaxial cable process, an Ishikawa diagram was obtained with the possible causes that generate the problem, a CTQ tree (Critics for quality, for its acronym in English), and the database where the defects that were presented are shown.

\section{Ishikawa diagram making}

This section shows the Ishikawa diagram that was obtained from the observation of the coaxial cable assembly process, as well as questions, were asked to the operators about what could cause the failure in the electrical test.
Figure 2 shows the Ishikawa diagram of the possible causes that generate the failure. The diagram shows a view of all the possible causes that affect the Failure of Electrical Test and Connectivity With this vision we can analyze in detail each cause and the effect it has on the process.

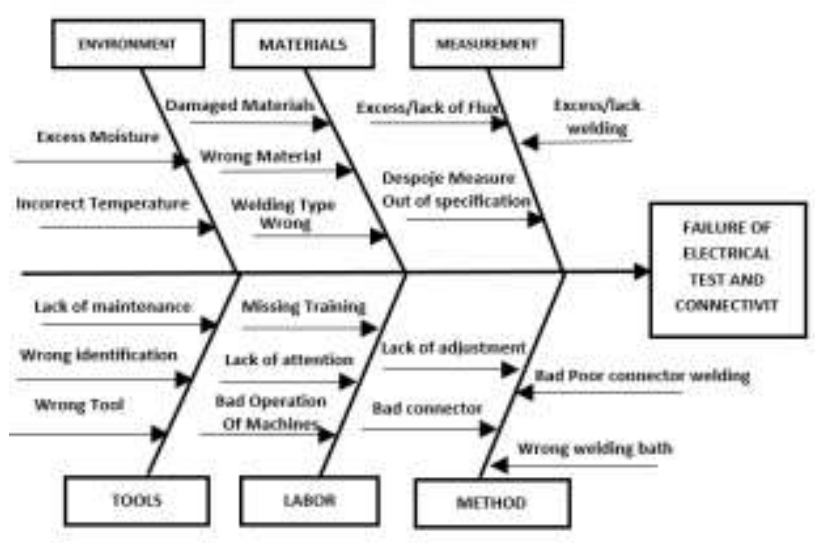

Figure 2 Ishikawa diagram of the process Prepared by the authors

\section{Elaboration of a tree of criticisms for quality.}

After determining the client's requirements, an analysis was carried out to know what relationship they have with the causes found in the Ishikawa diagram. Figure 5 shows the CTQ tree that was validated by the Process Quality Engineer.

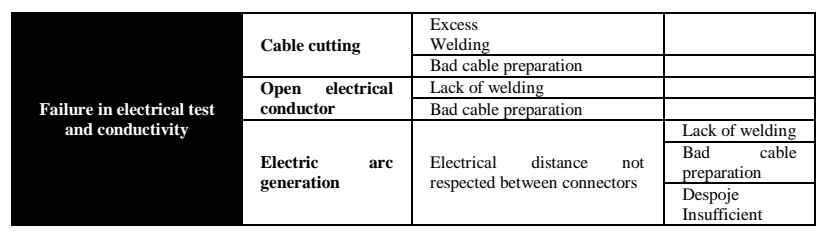

Figure 5 CTQ Tree. Prepared by the authors

Mapping of the process of assemblies of coaxial cables

At this point, a process mapping was carried out to identify all the variables that existed in each workstation, as well as their outputs, which could affect the electrical test and conductivity. Table 6 shows the variables and outputs of the process 


\begin{tabular}{|c|c|c|c|}
\hline X's & Process Variables & $\mathbf{Y}^{\prime} \mathbf{s}$ & Process Outputs \\
\hline $\mathrm{X} 1$ & Lack of operator training & Y1 & Strip wrong ends \\
\hline $\mathrm{X} 2$ & Wrong raw material & $\overline{\mathrm{Y} 2}$ & Damaged external protector \\
\hline $\mathrm{X} 3$ & Forward speed cutting machine & $\overline{\mathrm{Y} 3}$ & Damaged external conductor \\
\hline $\mathrm{X} 4$ & Calibration of cutting machine & $\mathrm{Y} 4$ & Damaged connector \\
\hline $\mathrm{X} 5$ & Stripping machine calibration & Y5 & No Welding Bath \\
\hline $\mathrm{X} 6$ & Rotary knife cutting speed & Y6 & Poorly placed central conductor \\
\hline $\mathrm{X} 7$ & Welding type & Y7 & C.C. Damaged \\
\hline $\mathrm{X} 8$ & Amount of welding & $\mathrm{Y} 8$ & $\begin{array}{l}\text { C.C. with excess welding } \\
\end{array}$ \\
\hline $\mathrm{X} 9$ & External welding application time & Y9 & C.C. with hollow or lack of sun \\
\hline X10 & Tipo de flux & Y10 & Misplaced pin (out) \\
\hline $\mathrm{X} 11$ & Amount of flux & Y11 & Melted insulator \\
\hline $\mathrm{X} 12$ & $\begin{array}{l}\text { Soldering iron temperature } \\
\end{array}$ & Y12 & Cut insulator \\
\hline X13 & $\begin{array}{l}\text { Power (temperature) of welding } \\
\text { clamps }\end{array}$ & Y13 & No contact pressing \\
\hline $\mathrm{X} 14$ & Pressing dimension & Y14 & Poor contact pressing \\
\hline $\mathrm{X} 15$ & Torque force & Y15 & External welding (Hollow, Missing) \\
\hline $\mathrm{X} 16$ & Wrong tool & Y16 & External Welding Spill \\
\hline $\mathrm{X} 17$ & Lid pressing height & Y17 & Internal Welding Spill \\
\hline $\mathrm{X} 18$ & Burn gun temperature & Y18 & Excess External Welding \\
\hline $\mathrm{X} 19$ & Wrong Pressing Given Tool & Y19 & No body torque \\
\hline $\mathrm{X} 20$ & Braid hairstyle & Y20 & Damage from body torque \\
\hline $\mathrm{X} 21$ & Splint placement & Y21 & No splint pressing \\
\hline $\mathrm{X} 22$ & Placement of PIN & Y22 & Poor splint pressing \\
\hline $\mathrm{X} 23$ & Type of flux & $\overline{\mathrm{Y} 23}$ & Splint and connector space \\
\hline $\mathrm{X} 24$ & Cutting knife condition & $\mathrm{Y} 24$ & short circuit between $\mathrm{CC}$ and $\mathrm{CE}$ \\
\hline $\mathrm{X} 25$ & Damaged raw material & Y25 & Open between contacts \\
\hline $\mathrm{X} 26$ & $\begin{array}{l}\text { Distance between dielectric and } \\
\text { central conductor }\end{array}$ & Y26 & Open between connector body \\
\hline $\mathrm{X} 27$ & Braid waste & Y27 & $\begin{array}{l}\text { Leakage current greater than } \\
\text { specification }\end{array}$ \\
\hline
\end{tabular}

Table 6 Process variables and outputs Prepared by the authors

\section{Elaboration of cause-and-effect matrix}

In this step, an array was made where the variables (X's) of the coaxial cable assembly process are compared with the process outputs (Y's). Likewise, the total that each input variable was calculated, based on this, the critical variables for the process were determined. As a result, the variables with the highest percentage of contribution were: Amount of welding (X20) with a percentage of $6,044 \%$, followed by the placement of the connector (X37) with a percentage of $4,925 \%$. Of the total of the variables that appear in the cause-and-effect matrix within $80 \%$ is the amount of welding, connector placement, wrong raw material, length of offal, PIN placement, braid combing, and amount of flux.

\section{Analysis of the data of the critical variables of the coaxial cable assembly process}

In this phase, the data obtained in the measurement phase were taken and a Pareto Diagram of the connectors with the greatest contribution to the generated problem was obtained, as well as the statistical analysis of the data.

\section{Pareto Chart Elaboration}

In this step, the Pareto diagram was obtained where the connectors that had the most appearance in failures in the electrical test and conductivity are shown.
Table 7 shows the types of connectors with the percentage of appearance of each of them, which contribute to the electrical failure, also in graph 2 is represented graphically.

\begin{tabular}{|c|c|r|r|r|}
\hline No. & \multicolumn{1}{|c|}{ Connector } & Occurrence & Cumulative Percentage & Percentage \\
\hline 1 & $\mathrm{~A}$ & 37 & $39.36 \%$ & $39.36 \%$ \\
\hline 2 & $\mathrm{~B}$ & 12 & $52.13 \%$ & $12.77 \%$ \\
\hline 3 & $\mathrm{C}$ & 10 & $62.77 \%$ & $10.64 \%$ \\
\hline 4 & $\mathrm{D}$ & 4 & $67.02 \%$ & $4.26 \%$ \\
\hline 5 & $\mathrm{E}$ & 3 & $70.21 \%$ & $3.19 \%$ \\
\hline 6 & $\mathrm{~F}$ & 3 & $73.40 \%$ & $3.19 \%$ \\
\hline 7 & $\mathrm{G}$ & 2 & $75.53 \%$ & $2.13 \%$ \\
\hline 8 & $\mathrm{H}$ & 2 & $77.66 \%$ & $2.13 \%$ \\
\hline 9 & $\mathrm{I}$ & 2 & $79.79 \%$ & $2.13 \%$ \\
\hline 10 & $\mathrm{~J}$ & 1 & $80.85 \%$ & $1.06 \%$ \\
\hline 11 & $\mathrm{~K}$ & 1 & $81.91 \%$ & $1.06 \%$ \\
\hline 12 & $\mathrm{~L}$ & 1 & $82.98 \%$ & $1.06 \%$ \\
\hline 13 & $\mathrm{M}$ & 1 & $84.04 \%$ & $1.06 \%$ \\
\hline 14 & $\mathrm{~N}$ & 1 & $85.11 \%$ & $1.06 \%$ \\
\hline 15 & $\mathrm{O}$ & 1 & $86.17 \%$ & $1.06 \%$ \\
\hline 16 & $\mathrm{P}$ & 1 & $87.23 \%$ & $1.06 \%$ \\
\hline 17 & Other & 12 & $100.00 \%$ & $12.77 \%$ \\
\hline & Total & 94 & & \\
\hline
\end{tabular}

Table 7 Types of connectors Prepared by the authors

As can be seen in graph 6 , connector A is the one that contributes the most to the electrical failure by having $39.36 \%$ of appearance, in second place, connector B with $12.77 \%$.

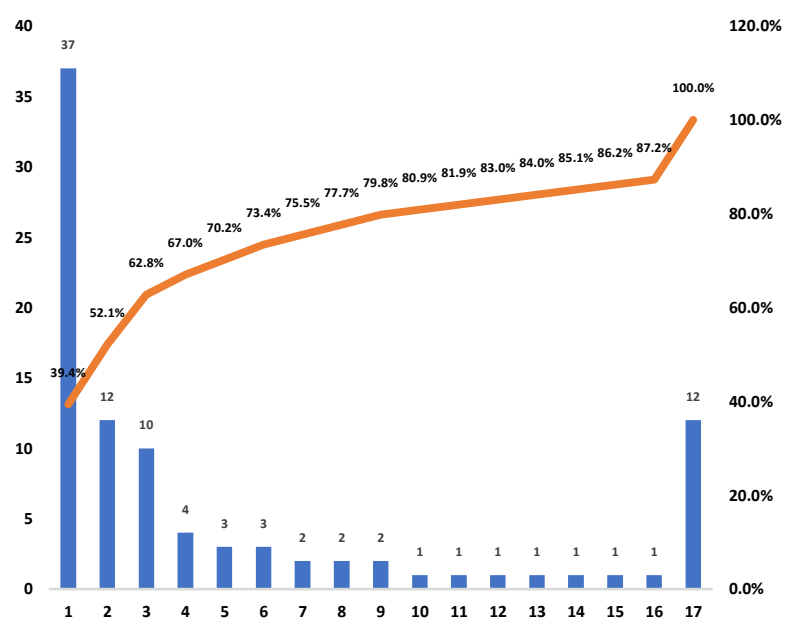

Graph 2 Pareto graph of connectors

Prepared by the authors

\section{Behavior analysis of variables}

In this step, statistical tests were performed on the variables that were identified as critical, to analyze them by regression and determine the relationship they had with the failure in the electrical test. 


\section{Behavior analysis of the variable welding quantity}

A sample of 10 cables was established to which a different amount of welding was applied, giving higher and lower values than the nominal established in the work route that is 0.75 inches of welding. And the volts that the cablesupported were measured as a result to corroborate that they passed the electrical test by having to withstand 1000 volts. Graph 3 shows the behavior that was obtained from this analysis.

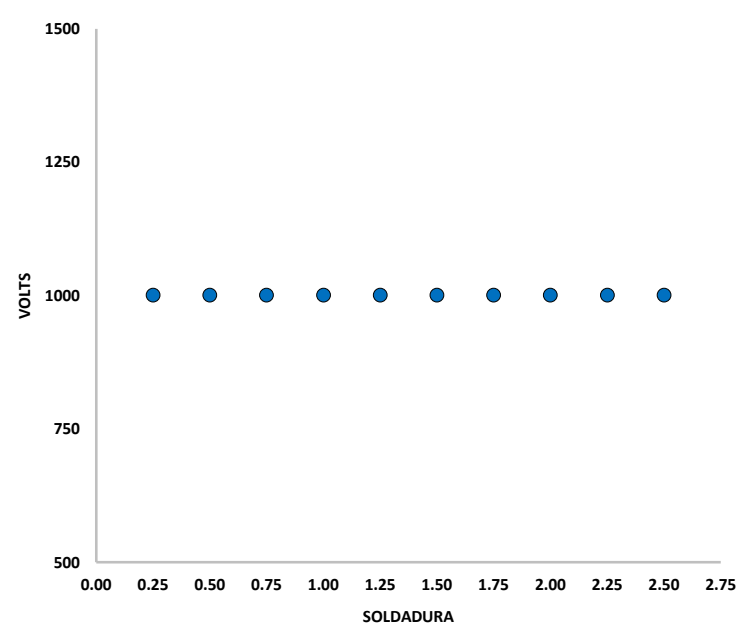

Graph 3 Plot Volts Vs Welding

Prepared by the authors

As can be seen in the graph above, the volts that each cable supports with the different amounts of welding does not have a significant effect on the number of volts they support. Therefore, the variable Welding Quantity is discarded when it is found that it has no relation to the output variable that is the failure in the electrical test because all the cables supported 1000 volts which was the minimum required.

Behavior analysis of the measured variable of the spoils.

To carry out this analysis, the diameter between the central conductor and the braid was taken as a reference. Modifications are made to the stripping of the nominal diameter that is 0.82 inches, giving it greater and lesser values. Taking, as a result, the volts that these supported, having to withstand 1000 volts to pass the electrical test. Graph 4 shows the behavior of this variable.

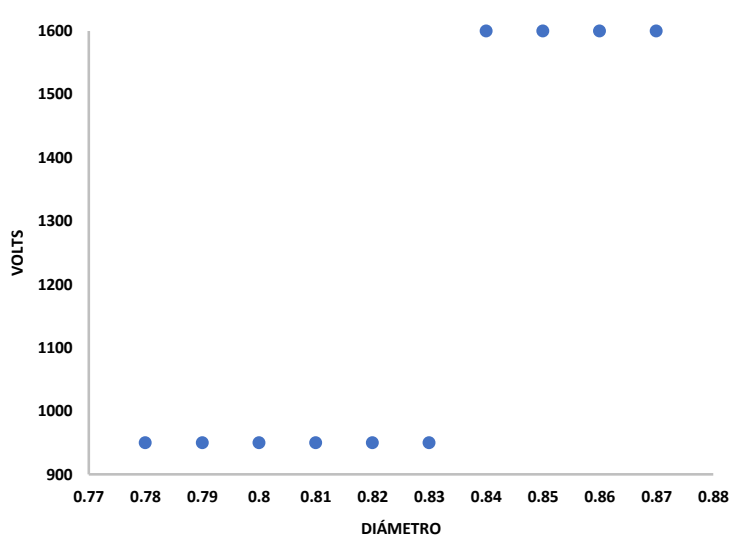

Graph 4 Plot of Volts vs. Diameter Prepared by the authors

As can be seen in the graph above, 7 of the 10 cables did not withstand the minimum number of volts required to pass the electrical test, which indicates that the separation diameter is related to the voltage that the cables support by having a smaller diameter of separation the cables support less voltage. With the above, it is determined that the variable measures of stripping are related to the output variable that is the failure in the electrical test.

Implementation of improvement actions for the coaxial cable assembly process

In this phase, the data of the connectors with the highest contribution of occurrences established in the Pareto diagram of the Analysis Phase were taken, as well as the critical variables that were obtained after the behavior analysis of the variables. The type B connector was taken for the design of experiments due to the availability of materials that were within the area. Obtaining a Design of Experiments and the implementation of this.

Planning for Design of Experiments connector type B

In this section, the design of experiments to be carried out for the type B connector with the stripping measurement and pressing method factors was carried out. Table 8 shows the factors to be considered, as well as the levels that were granted to each of them

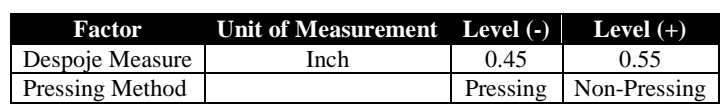

Table 8 Design Factors of Experiments connector type B Prepared by the authors 
In the table above it is observed that two levels were given to each factor within the design of experiments, for the Measure of the Despoje 0.45 and 0.55 inches, and the Method of Pressing, pressing, and not pressing.

\section{Design Result of Experiments type B connector}

After the execution of the design of experiments proposed in the previous point, Table 9 shows the results that were obtained.

\begin{tabular}{|lrrrr|r|r|}
\multicolumn{1}{c}{ Source } & \multicolumn{1}{c}{ gl } & \multicolumn{1}{c}{$\begin{array}{c}\text { Sc } \\
\text { Adjusted }\end{array}$} & \multicolumn{1}{c|}{ MC Adjusted } & \multicolumn{2}{c|}{ Value F } & \multicolumn{1}{c|}{ Value p } \\
\hline Model & 3 & 687500 & 229167 & 11.00 & 0.001 \\
\hline Lineal & 2 & 625000 & 312500 & 15.00 & 0.001 \\
\hline Measure & 1 & 562500 & 562500 & 27.00 & 0.000 \\
\hline Method & 1 & 62500 & 62500 & 3.00 & 0.109 \\
\hline Interactions of 2 Terms & 1 & 62500 & 62500 & 3.00 & 0.109 \\
\hline Measure*Method & 1 & 62500 & 62500 & 3.00 & 0.109 \\
\hline Error & 12 & 250000 & 20833 & & \\
\hline Total & 15 & 937500 & & & \\
\hline
\end{tabular}

Table 9 Experiment Design Results Prepared by the authors

As shown in the table above, the Measurement factor, since its $p$-value is less than 0.05 , indicates that the hypothesis that the means are equal is accepted, that is, there is no significance between them. On the other hand, the Method factor having a p-value greater than 0.05 indicates that the hypothesis that the means are equal is rejected, that is, there is statistical significance between them. Graph 5 shows the behavior of the factors on the Volts output variable.

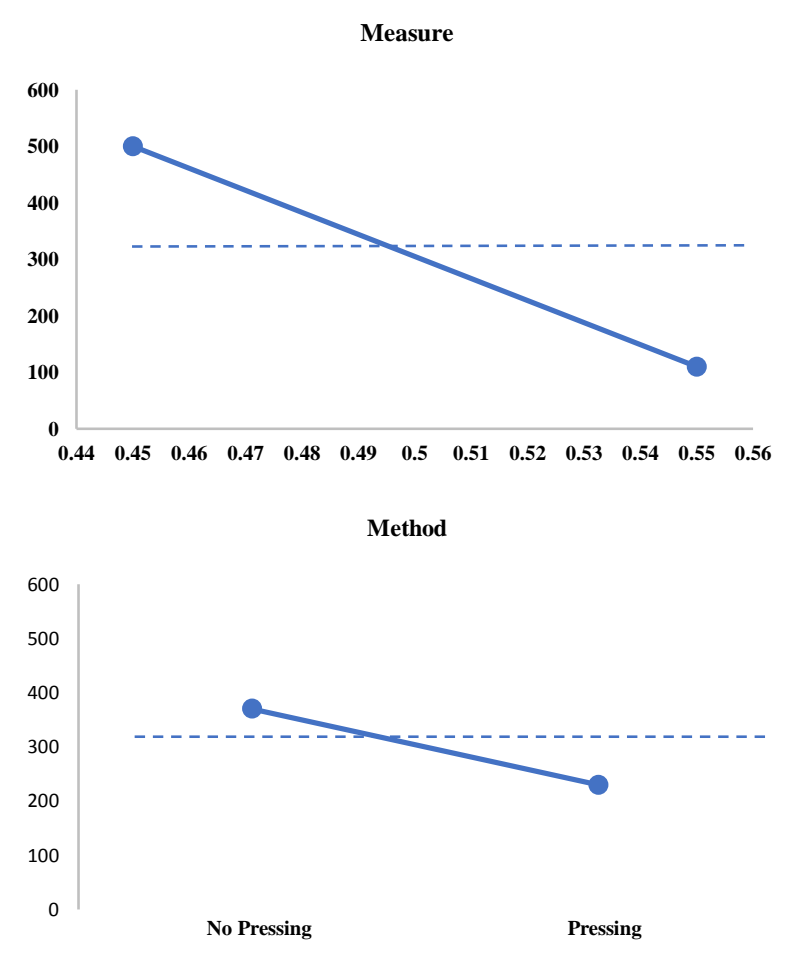

Graph 5 Main effects graph for volts

Prepared by the authors
The graph above shows that the NonPressing Method is better than the Pressing Method, likewise indicating that the measure of 0.45 is better than 0.55 . Therefore, the best yields are found in non-pressing and a stripping measure of 0.45 inches.

Development of proposals for improvement to the area of assembly of coaxial cables

After the execution of the design of experiments and the interpretation of the results that were obtained from it, it is taken as an improvement proposal for the process of assemblies of coaxial cables is that a change is made in the measure of stripping that is had for the cables that carry the connector type $\mathrm{B}$, reducing this to 0.45 inches, so that a greater separation between the central conductor and the braid is obtained. With the above, the possibility of a short in the cable is reduced and with this the failure in the electrical test.

\section{Conclusions}

During the time in which the present project was developed in the company under study, to analyze and find solutions that help reduce the defects that affect the electrical test and conductivity, it was found that there were a high number of variables present in the process of assemblies of coaxial cables that could contribute to the presentation of the fault.

To find proposals that help improve the process, it was necessary to make exhaustive observations of the process, to identify each of the variables that affected it and in turn specify these in each season of the process. Thus, generating a list of all the variables of the process.

Continuing with an analysis of the variables to determine which were critical to the process, that is, which had a greater effect on the failure of the electrical test. Since it is very important to discard the variables that do not significantly affect the problem. At the moment that the significant variables of the project are had, the design of experiments is carried out to know the behavior of these variables on the expected result, which is that the cables pass the electrical and conductivity test. Obtaining from this a proposal to improve the process that consists of modifying the stripping measure from 0.55 inches to 0.45 inches for the type B connector.

PORTUGAL-VÁSQUEZ，Javier， SANDOVAL-GAMEZ， Melissa, LAGARDA-LEYVA, Ernesto Alonso and NARANJO-FLORES, Arnulfo Aurelio. Proposals to improve the coaxial cable assembly process in an aerospace company. Journal of Research and Development. 2021 


\section{References}

Aguirre Sigala, K. \& Pereyda Martinez, J. (2010). Implementar la Metodología Seis Sigma para Reducir el Desperdicio en el Proceso de Fundición a Presión en Radver. (Tesis de Licenciatura, Instituto Politécnico Nacional). México, DF. Recuperado de http://tesis.ipn.mx/bitstream/handle/123456789/ 7364/I7.1904.pdf? sequence $=1$

Cantú Delgado, J. H. (2011). Desarrollo de una Cultura de Calidad (4 ed.). México, DF: McGraq-Hill Interamericana.

COPRESON. (2012). Consejo para la Promoción Económica en Sonora. Obtenido de http://es.sonora.org.mx/index.php/industria\#

FAM, \& SEDENA. (2015). Fuerza Area Mexicana. Obtenido de http://www.fairmexico.com.mx/feria-aeroespacial-mexico2015/aeronautica-en-mexico/industriaaeroespacial-mexicana

FEMIA, \& Económia, S. d. (2013). Secretaría de Económia. Obtenido de http://www.economia.gob.mx/files/comunidad_ negocios/industria_comercio/proaereo_bueno.p df

Forbes. (2014). Forbes México. Obtenido de http://www.forbes.com.mx/industriaaeroespacial-un-nuevo-reto-para-las-empresasmexicanas/

García, D. (s.f.). Solucion de Problemas: 8 Disciplinas. TÜV RHEINLAND DE MÉXICO.

Gutierrez Pulido, H., \& De la Vara Salazar, R. (2013). Control Estadistico de la Calidad y Seis Sigma (Tercera ed.). México D.F: McGRAWHILL.

Gutierrez, H. (2014). Calidad y Productividad (4 ed.). México, D.F: Mc Graw Hill.

Gutierrez, H., \& De la Vara, R. (2012). Analisis y Diseño de Experimentos (3 ed.). México, D.F: Mc Graw Hill.

Gutierrez, H., \& De la Vara, R. (2012). Análisis y Diseño de Experimentos. McGraw-Hill Interamericana.
Gutierrez, H., \& De la Vara, R. (2013). Control Estadístico de la Calidad y Seis Sigma (3 ed.). McGraw Hill Education.

INEGI. (2012). Cuentame INEGI. Recuperado el 23 de Enero de 2015, de http://cuentame.inegi.org.mx/monografias/infor macion/son/economia/pib.aspx ?tema $=$ me\&e $=2$ 6

INEGI. (2012). INEGI. Recuperado el 23 de Enero de 2015, de http://www3.inegi.org.mx/sistemas/mexicocifra s/default.aspx?e=26

INEGI. (2014). INEGI. Obtenido de http://cuentame.inegi.org.mx/economia/secunda rio/manufacturera/default.aspx?tema=E\#uno

Ingeniería, O. d. (2011). Observatorio de la Ingeniería. Obtenido de http://www.observatoriodelaingenieria.org.mx/i ng_det.php?Tema $=$ Nichos\&Nicho $=1$

LRQA. (2015). LRQA México. Recuperado el 26 de Enero de 2015, de http://www.lrqamexico.com/certificaciones/AS9100-Gestion-Aeroespacial/

Medina, S. (2012). Bancomext. Obtenido de $\mathrm{http} / / /$ revistas.bancomext.gob.mx/rce/magazine s/151/1/Nov-Dic_3-9.pdf

Montgomery, D. (2004). Diseño y Análisis de Experimentos (2 ed.). Limusa Wiley.

Pande, P., \& Holpp, L. (2002). ¿Que es Seis Sigma? McGRAW-HILL.

Pande, P., Neuman, R., \& Cavanagh, R. (2004). Las Claves Prácticas de Seis Sigma. McGraw Hill.

ProMéxico. (2014). ProMéxico. Obtenido de http://mim.promexico.gob.mx/wb/mim/perfil_d el_sector

Santiago, A., Pérez, I., Ruíz, M., \& Guevara, N. (2014). Reducción de Defectos por Medio de Seis Sigma. En I. Pérez Olguín, Ingenieria de Procesos: Casos Prácticos (págs. 76-83). Universidad Tenologica Ciudad Juarez.

Sobek, D., \& Smalley, A. (2008). Understanding A3 Thinking: A Critical Component of Toyota's PDCA Management System. CRC Press. 
Tolamatl, J., Gallardo, D., Varela, J., \& Flores, E. (2011). Aplicación de Seis Sigma en una Microempresa del Ramo Automotriz. Conciencia Tecnologica, 11-18. 